\title{
Motivational analysis during one season in female football in Castilla y León (Spain) \\ Análisis motivacional durante una temporada de fútbol femenino en Castilla y León (España)
}

\author{
Marta Zubiaur González, Sheila Pinilla San José, M anuel Ángel Villamarín González \\ Universidad de León (España)
}

\begin{abstract}
Despite the importance of football in today's society, little research has been done on femal e football. The principal aim of this investigation is to find out why women participatein this sport, to identify goal orientations, as well as to analyse the perceived motivational climate and differences according to category and stage of the season in women'sfootball. In order to achieve this, we have used a sample of 41 femal e football players belonging to three different football clubs of C astillay León in three different ranks ( $1^{\text {\} } \text { Regional B Football } 11,1^{\star} \text { Regional Futsal, and } 2^{\text {nd }} N \text { ational Football } 11 \text { ), aged between } 15 \text { and }$ 19 years old, which were administered the Sport M otivation Scale by Pelletier et al. (1995), the Task and Ego O rientation in Sport Questionnaire by Duda and Nicholls (1989) and the Perceived Motivational Climate in Sport Questionnaire2 by Newton et al (2000). Results reveal that the subjects present more Intrinsic than Extrinsic M otivation and obtained low rating values in Amotivation. Referring to the goal orientation matter, evidence confirms that the levels ofTask $O$ rientation are higher than to Ego in every rank, with the latter decreasing throughout the season. In every team, the subjects perceived a greater Taskinvolving climate than to Ego-involving, al though higher values in the Ego-involving climate were achieved in the $2^{\text {nd }} \mathrm{N}$ ational Football 11 compared to the other ranks.
\end{abstract}

Keywords: Female football, motivation, goal orientation, self-determination.

Resumen. Pese a la importancia del fútbol en la sociedad actual hay pocos estudios que se centren en el fútbol femenino. El objetivo de este trabajo es conocer las razones de participación en el deporte, identificar las orientaciones de meta, así como anal izar el clima motivacional percibido y las diferencias existentes en función de la categoría y la etapa de la temporada en el fútbol femenino. Para ello, se empleó una muestra de 41 futbolistas femeninas pertenecientes a tres clubes de fútbol de

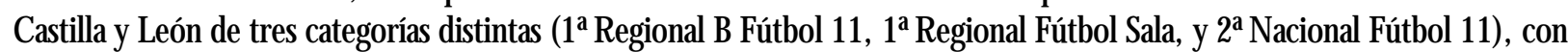
edades comprendidas entre 15 y 29 años, a las cuales se les administraron la Escala de Motivación Deportiva de Pelletier et al. (1995), el Cuestionario de Orientación a la Tarea y al Ego de Duday N icholls (1989) y el Cuestionario de Clima M otivacional Percibido en el D eporte de N ewton et al. (2000). Losresultados revelan que las participantesmostraron una mayor M otivación Intrínseca queExtrínsecay obtuvieron unos val ores bajos enAmotivación. En relación alasorientaciones de meta, en todas las categorías aparecen valores más elevados en la 0 rientación a latareaqueal ego, con un descenso de estaúltimaalo largo de latemporada. En todos los equipos, las participantes percibieron un mayor Clima de implicación hacia laTarea que al Ego, aunque en la 2a N acional Fútbol 11 alcanzaron valores más elevados en Clima de implicación al Ego respecto a las otras dos categorías. Palabras clave: Fútbol femenino, motivación, orientaciones de meta, autodeterminación.

\section{Introduction}

Women's football is currently experiencing a growing trend in the number of licences granted by the Spanish Football Federation (Consejo Superior de Deportes, 2019), as well as in the participation in major European and world events. Football, besides being a spectacle, isacomplex sport that requiresgreat technical, tactical and psychological skills (Navarrón, Asenjo \& Rodríguez, 2012). Analysing the psychological variables that interact is pivotal for those who practise it, since it

Fecha recepción: 10-02-20. Fecha de aceptación: 06-10-20

Marta Zubiaur Gonzalez

mzubg@ unileon.es allows to train mentally the athletes to achieve the optimal psychological state that improves their performance. W ithin these variables, motivation plays a fundamental role in the improvement of all aspects (physical, psychological and social) that involvethissport, and helps to achieve not only greater commitment and adherence to it (Iso-Ahola \& St.Clair, 2000), but also better results (Fernández-Ríos, Cecchini $\&$ MéndezJiménez, 2017).

Motivation in sport has been studied from different perspectives. Deci and Ryan (1985), in their theory of Self-Determination, assume that people tend to psychological growth and development, as long as they find support for their basic psychological needs, which are fundamentally those of autonomy, competence and 
relatedness (Deci \& Ryan, 2000). The satisfaction of these needs explains the behaviour of individuals al ong a motivational continuum, which ranges from Amotivation to Intrinsic Motivation, through Extrinsic Motivation. Motivation is intrinsic when sport is practised only for pleasure, so the activity is performed without external reinforcements or rewards. Vallerand, Blais, Brière and Pelletier (1989) suggest that it is a multidimensional construct where three subtypes can be distinguished: firstly, the Intrinsic M otivation to know, which means that sport practice is carried out for pleasure and the feeling that the sportsperson enhances when they learn; secondly, the Intrinsic M otivation to experiment, based on sport practice for enjoyment, but also to sense something else from usual perceptions; and thirdly, the Intrinsic Motivation to achieve results, which attributes sport training to the delight and fulfilment experienced when exercise, movements or new positions are performed correctly). Motivation is extrinsic when sportswomen act upon external reinforcements or rewards: money, grants, trophies, social acknowledgement, etc. (Moreno, Cervelló \& González-Cutre, 2007). Within extrinsic motivation, Deci and Ryan (1985) propose a multidimensional perspective with four subtypes that vary according to the degree of autonomy: firstly, the Integrated regulation, which is the most autonomous form and occurs when behavior isnot only considered valued, but also congruent with the other goals, objectives and needs of the individual's life; secondly, the Identified regulation, where althougt sport is trained under external control, the athlete has a higher level of autonomy available and the ability to make decisions in order to achieve this self-dependence (Moreno et al., 2007); thirdly, the Introjected regulation, where sport is practised on a regular basison an external demand, but with an internal reward that fosters self-esteem and selfaccomplishment, but still without autonomy; and finaly, the External regulation, in which autonomy is absent, and sport is practised either under somebody else's request, either for future rewards. External regulation and Introjected regulation represent the lowest levels of self-determination, Identified the medium level, and Integrated regulation would represent the highest level of Self-determined behavior influenced by external activity considerations (Deci \& Ryan, 1985; Balaguer Castillo \& Duda, 2007). Amotivation represents the lack of both types of motivation, consists of non-regulation and a lack of intention to sport practice (Deci \& Ryan, 1985; Ryan \& Deci, 2020).
On the other hand, to under stand motivation in sport it is important to analyse goal orientations in achievement contexts The Achievement Goal theory (Nicholls, 1984) claims that in achievement settings, such as sports, the main goal of individuals is to demonstrate competence, and there are two different ways of interpreting this competence in terms of personal goal orientation. Nicholls (1984) defines two different goal orientations: Ego Orientation, if the athlete is stimulated by the competition with the others, testing and comparing his capacity levels, both at goal and ability levels; and Task 0 rientation, if the athlete is encouraged by his mastery and personal progress, examining both their level of ability and selfimprovement (M oreno et al., 2007).

The competitive level of the athletes may influence on the strength and type of goal orientations they show. Players of the National Basketball Team consider the willingness to compete and the desire to win as indispensable psychological aspects in the study by SáenzLópez, Jiménez, Giménez and Ibáñez (2007). Likewise, García-N aveira and Remor (2011) find higher scores in success motivation and in competitiveness trait depending on the level of professionalization in football players.

These goal orientations may be influenced by the environment or motivational climate in which they operate, so that both trainer and teammates can generate a climate of ego or task involvement, thus affecting motivation (N ewton, Duda \&Yin, 2000). Ego-involving climate occurs when the coach is characterized by decisions of unequal recognition (offering more attention and help to the most talented athletes), of punishment for mistakes (responding negatively to them) and of promoting intra-group rivalry (causing social comparison and competitiveness among athletes). $0 \mathrm{n}$ the other hand, task-involving climate happenswhen the coach is characterised by decisions of effort and improvement recognition (they appreciate hard work, that everyone tries their best), for the recognition of every role (they make possible that each athlete has a key role and contributes to success), and for cooperative learning (they value cooperation and improvement) (Galván, López, Pérez, Tristán \& M edina, 2013).

Research shows a positive relationship between task orientation and intrinsic motivation (Álvarez, Castillo, Duda\& Balaguer, 2009; N toumanis, 2001), which makes sense since task orientation is an adaptative approach to achieving goals, which encourages them to engage in sport. 
On the other hand, scientific literature proves the importance of the climate transmitted by the coach as a predictor of the motivation of athletes and their commitment to sport (Torregrosa, Sousa, Viladrich, Villamarín \& Cruz, 2008). More precisely, it is tested that a task-oriented climate promotes effort, selfimprovement and the rise of their motivation (Almagro, Sáenz-López, González-Cutre \& Moreno, 2011; Almagro, Sáenz-López \& Moreno, 2012; Ceccini, González, López-Prado \& Brustad, 2005), which facilitates a greater conscious commitment to sport. This is especially relevant in young athletes, as Torregrosa et al. (2008) have proved with male football players and Iwasaki and Fry (2016) with female football players.

Since motivation and motivational climate are determining for any sport, it is logical to find a great variety of studies concerning football (Álvarez et al., 2009; Barroso, Lopes \& De Marco, 2017; Fernández, Yagüe, M olinero, Márquez \& Salguero, 2014; M onteiro, M outão, Baptista, \& Cid, 2014; Sarmento et al. , 2014; Sarmento, Peralta, Harper, Vaz \& Arques, 2018); however, there are few studies that anlyse female football hence the value of this research.

Based on the fact that the ultimate goal of any season is the evolution and improvement of every skill including psychological ones - we considered relevant to keep track of motivation along the season. 0 ur aim in this work, therefore, consists of analysing the motivation of three female football teams of to three different categories, i. e. different levels of competition (ascending order: $1^{\text {st }}$ Regional B Football $11,1^{\text {st }}$ Regional Futsal and $2^{\text {nd }} \mathrm{N}$ ational Football 11$)$, by making a longitudinal study of the motivational climate through awhole season (beginning, middle and end) which allows us to evaluate the possible changes of the psychological variables to be studied. We also intend to observe whether there are differences according to the level of competition in terms of intrinsic motivation, goal orientation and perceived motivational climate, as well as to analyse possible relationships between variables.

\section{Materials and M ethods}

\section{Participants}

The sample consists of 41 female football players from the community of Castilla y León (Spain): 13 players from J uventud Rondilla - UEMC S.C., Valladolid ( $1^{\text {st }}$ Regional B Football 1l), 12 playersfrom San Roque Carbajosa de la Sagrada S.C., Salamanca ( $1^{\text {th }}$ Regional
Futsal) and 16 playersfrom León Fútbol Femenino S.C., León ( ${ }^{\text {nd }} \mathrm{N}$ ational Football 11 ). All the players participated voluntarily in this study and under express authorisation by signing an informed consent form.

The football players range in age from 15 to 29 years old, (1 $1^{\text {st }}$ Regional B Football 1l M: 21.46, DT: 3.53; $1^{\text {st }}$ Regional Futsal $M: 22.92, D T: 4.48 ; 2^{\text {nd }} N$ ational Football 1l M: 20, DT: 3.79). The requirement for the participation in the present research was to be able to carry out three questionnaires (one at the beginning, other at the half and the last one at the end of the season). The initial sample consisted of 46 players, five of whom were excluded for not completing any of the three questionnaires, as well as for leaving the team before the end of the season. Thus, the sample remained at 41 players.

\section{Measures}

In order to realise this investigation, three different questionnaires were provided:

1st. As a way of knowing why these players practise football, they were provided with the «Sports M otivation Scale» (SMS) by Pelletier, Fortier, Vallerand, Tuson, Briere and Blais (1995), used in the Spanish version by Bal aguer, Castillo and Duda (2003; 2007) with Spanish sportsmen. This test consists of 28 questions involving a 7-point Likert-type scale, indicating in the answer if It has nothing to do with me (1-2), It has something to do with me $(3,4,5)$ or It complies fully with me $(6,7)$. Its main purpose is to analyse three different factors: firstly, Intrinsic Motivation, which is further divided into Intrinsic Motivation to Know, Intrinsic Motivation to Experiment and Intrinsic M otivation to A chieve Results. Secondly, Extrinsic M otivation, which splitsinto Extrinsic Motivation from External Regulation, Extrinsic Motivation from Introjected Regulation and Extrinsic Motivation from Identified Regulation; and thirdly and finally, Amotivation. Previous studies have confirmed adequate internal reliability and factorial validity, the construct validity was supported and factorial validity for this scale (Balaguer et al., 2007, Núñez Alonso et al., 2007). The scale has found reliable internal consistency: Cronbach's al pha values varying between .70 and .88, except for the External Regulation $(\alpha=.63)$ and Identified Regulation ( $\alpha=.61)$.

2nd. In order to identify the players' tendency towards ego and task, Duda and Nicholl'sTask and Ego O rientation in Sport Q uestionnaire (TEOSQ) (1989) elaborated in the Spanish version by Balaguer, Castillo andThomas (1996) and adapted to football (Balaguer et 
al. , 2003), was provided. This questionnaire comprises 13 items: 6 Ego-oriented and 7Task-oriented. It should be answered with a 5-point Likert-scale, varying from Strongly disagree to Totally agree, regarding the issues they feel more successful with in football practice. The internal consistency of the scales, analyzed with Cronbach's al pha, has given very acceptable values (Task, $\alpha=.82$, and Ego, $\alpha=.88$ ). Previous studies have confirmed adequate internal reliability and factorial validity for this scale (Balaguer et al., 1996; Ruiz-Juan et al., 2014).

3rd. To assess the perceived motivational climate created by the coach, the participants completed the Spanish version (Balaguer, Mayo, Atienza \& Duda, 1997) of the Perceived Motivational Climate in Sport Questionnaire-2 (PMCSQ -2) (Newton et al., 2000; Walling, Duda \& Chi, 1993). This questionnaire entails 29 items (14 ego-involving and 15 task-involving) and should be answered with a 5-point Likert-scale, which ranges between Strongly disagree and Totally agree, regarding their perception about the climate created by the trainer. Previous studies have confirmed adequate internal reliability and factorial validity for this scale (Balaguer et al., 2003; N ewton et al., 2000). The Cronbach's alpha was: Task, $\alpha=.92 ;$ and Ego, $\alpha=$ .84 .

\section{Procedure}

The study was conducted during the 2017/ 2018 season.

Firstly, the clubs and coaches of each team were contacted to explain what the study was about and to request their participation if they were interested. 0 nce the clubs and the coaches had given their approval, a meeting was held with the players of each team was held with the aim of explaining what the study was about, to solve their doubts and to provide them with the informed consent document, which they had to return signed, giving their consent and accepting participation, in accordance with the ethical principles for medical research involving human subjects of the Helsinki Declaration (2018).

The questionnaires were administered by the researchers in person to resolve possible doubts that may arise. The SMS/ EMD scale was passed only at the beginning of the season, in September, whiletheTEO SQ and PCM SQ -2 questionnaires were passed in September at the beginning, then in the middle of the season, during the month of January, and finally in the months of A pril and May coinciding with the end of each club's season. All the questionnaires were completed on the first training session; otherwise the results obtained in the competition or the sensations obtained in the training sessions could interfere in the participants' answers.

The classification of the teams in the 2017/ 2018 competitions were similar: $2^{\text {nd }} \mathrm{N}$ ational Division Football 11 (León F. F., León O lympic) 9th Position out of 14; $1^{\text {st }}$ Regional B Division Futsal (San Roque) 6th position out of 10; and $1^{\text {st }}$ Regional $B$ Division Football 11 (RondillaYouth) 7th position out of 14.

\section{Data analysis}

The design of this study was observational and descriptive of a longitudianl nature. All data were analyzed using IBM SPSS 24. First, exploratory analyses were conducted to establish whether data met parametric assumptions. The Shapiro-Wilk test showed that five of the dependent variables were not normally distributed $(p<.05)$. Therefore, non-parametric tests were used. Initially, a descriptive analysis of the questionnaires was conducted, followed by an analysis of the differences between categories with the KruskalWallis test, and a post hoc analysis was carried out using the M ann-Whitney $U$-test. The relationships between the study variableswere studied using the Spearman correlation coefficient. Finally, the analysis of the evolution of the datathrough the season within each category was carried out with the Wilcoxon range test.

\section{Results}

\section{Reasons why players play football}

The analysis of the «Sports M otivation Scale» (SMS/ EMD) shows that the average score of Intrinsic

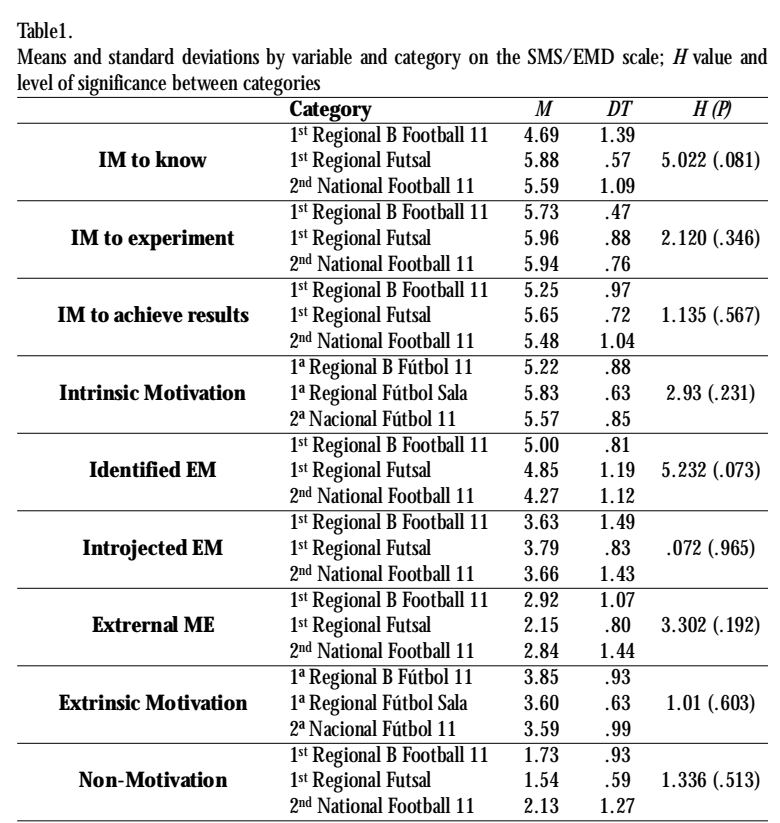


Motivation, is higher than that of Extrinsic M otivation, and that the lowest average is attributed to the Amotivation variable, as shown in Table $1 . W$ ithin Intrinsic Motivation, the variable that has the highest average is Intrinsic Motivation to Experiment versus Intrinsic M otivation to Know that has the lowest values. W ith respect to Extrinsic Motivation, the variable by Identified Regulation has the highest mean and Extrinsic M otivation by External Regulation the lowest mean.

TheK ruskal-Wallistest conducted to study any possible difference by category does not show significant results in any variable, showing a fairly similar motivational profile for all players in our study regardless of category (Table 1).

\section{Players' goal orientations}

O nce the data acquired through the «Q uestionnaire of Ego and Task Orientation in Sport» (TEOSQ) has been collected, by carrying out the analysis we can see in Table 2 that during the whole season the averages of Task O rientation are much higher than those of Ego 0 rientation.

The Kruskal-Wallis test does not show any significant difference between the categories, both in Ego and Task 0 rientation, showing similarity between the groups throughout the season (Table 3).

\begin{tabular}{|c|c|c|c|c|c|}
\hline Season & Category & $\begin{array}{l}\text { Task Or. } \\
\text { M (DT) }\end{array}$ & $\begin{array}{l}\text { Ego Or. } \\
\text { M (DT) }\end{array}$ & $\begin{array}{c}\text { Task Climat } \\
\text { M (DT) }\end{array}$ & $\begin{array}{l}\text { Ego Climate } \\
M(D T)\end{array}$ \\
\hline \multirow{4}{*}{ Begining } & $1^{\text {st }}$ Regional B F. 11 & $4.33(.52)$ & $1.97(.94)$ & $4.25(.57)$ & $2.04(.25)$ \\
\hline & 1st Regional Futsal & $4.57(.33)$ & $1.92(.79)$ & $4.52(.32)$ & $2.17(.33)$ \\
\hline & $2^{\text {nd }} N$ ational F. 11 & $4.46(.51)$ & $2.07(.02)$ & $3.74(.98)$ & $3.09(.83)$ \\
\hline & TOTAL & $4.46(.45)$ & $1.99(.92)$ & $4.17(.62)$ & $2.43(.47)$ \\
\hline \multirow{4}{*}{ Half } & $1^{\text {st }}$ Regional B F. 11 & $4.26(.35)$ & $1.71(.69)$ & $4.42(.31)$ & $1.85(.30)$ \\
\hline & 1st Regional Futsal & $4.45(.45)$ & $2.08(.76)$ & $4.20(.46)$ & $2.30(.54)$ \\
\hline & $2^{\text {nd }}$ National F. 11 & $4.26(.55)$ & $2.05(.89)$ & $3.37(.98)$ & $2.89(.80)$ \\
\hline & TOTAL & $4.33(.45)$ & $1.95(.78)$ & $3.99(.59)$ & $2.34(.55)$ \\
\hline \multirow{4}{*}{ End } & $1^{\mathrm{st}}$ Regional B F. 11 & $4.40(.47)$ & $1.82(.81)$ & $4.44(.30)$ & $1.96(.31)$ \\
\hline & $1^{\text {st }}$ Regional Futsal & $4.54(.48)$ & $1.98(.60)$ & $4.14(.50)$ & $2.50(.50)$ \\
\hline & $2^{\text {nd }} N$ ational F. 11 & $4.16(.57)$ & $1.98(.80)$ & $3.36(.77)$ & $2.66(.44)$ \\
\hline & TOTAL & $4.36(.51)$ & $1.93(.74)$ & $3.98(.52)$ & $2.37(.44)$ \\
\hline
\end{tabular}

Goal orientations per category and season

W hen comparing the results obtained throughout the three moments of the season in Ego and Task 0 rientation, the Wilcoxon range tests do not show significant results in the 1st Regional Futsal and $1^{\text {st }} \mathrm{Re}-$ gional B Football categories. However, in the 2nd National Football 11 category, although there are no differences in Ego Orientation either, the analysis of

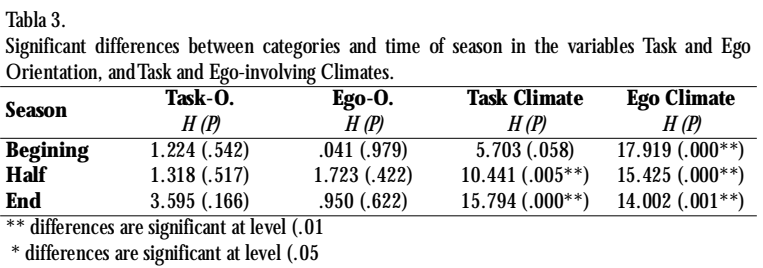

Task 0 rientation shows differences between the beginning and the end of the season ( $Z:-2.619 ; p:$. 009), decreasing as the season progresses.

\section{Motivational climate of involvement in the Ego or Task perceived by the players}

The analysis of the data from the $« Q$ uestionnaire on M otivational Climate Perceived in Sport» (PMCSQ -2) shows that, during the whole season, the averages of the perception Task-involving climate are clearly higher than those of the Ego-involving climate (Table 2).

TheKruskal-Wallistest conducted to study any possible difference by category shows significant differences between the groups in the three stages of the season, regarding the Ego-involving climate (Table 3). The post hoc analysis by means of the M annW hitney $U$-test, indicates that these differences are due, fundamentally, to the higher scores of the 2nd National Football 11 category in relation to the other two at both the Beginning and the Middle of the season, but al so to the lower scores of the 1st Regional Football 11 category at the Middle and End of the season (Table 2).

Also with regard to the perception of aTask-involving climate, significant differences can be seen between the categories throughout the season (Table 3). The post hoc analysis by means of the Mann Whitney $\mathrm{U}$-test, allows us to observe that the differences are due to the scores of the 2 nd $N$ ational Football 11 category being clearly lower than in the rest (Table 2).

\subsection{Perceived climate by category and season}

When comparing the results obtained throughout the three moments of the season in the perceptions of the Ego-Task-involving climates, the Wilcoxon range tests show significant results in the 1st Regional Futsal category, where a significant increase in the perception of the Ego-involving climate is observed, progressive from the Beginning to the End of the season (BeginningMidle Z: -2.339 p: .016; Beginning-End Z:-2.478, p: .013). Inversly, in the same category, the perception of an Ego-involving climate increases throughout the season (Beginning-End Z: -2.002, p: .045). However, in 1st Regional Football 11 category, the perception of the Climate to the Ego decreases significantly at the middle of the season ( $Z:-2.174, p:$.030), rising again at the End of the season.

\section{Relationships between variables}

The correlation analysis between variables (Table 4) shows us that the three Intrinsic M otivation subscales correlate negatively with Ego 0 rientation and positively 
with Task Orientation. However, the Extrinsic Motivation subscales barely present significant correlations, except for the identified regulation, which correlates negatively with Ego 0 rientation and positively with Task 0 rientation. W ith respect to Motivational Climate, Amotivation and Ego 0 rientation are positively correlated with Ego-involving climat, and Extrinsic Motivation by Regulation is negatively correlated with it. On the other hand, with Taskinvolving climate, Intrinsic Motivation to experiment and to achieve results shows positive relations, and with Extrinsic Motivation by identified regulation: $0 \mathrm{n}$ the other hand, Amotivation shows negative correlations with Task O rientation and Task-involving climate, and positive correlations with Ego 0 rientation and Egoinvolving climate quite pronounced.

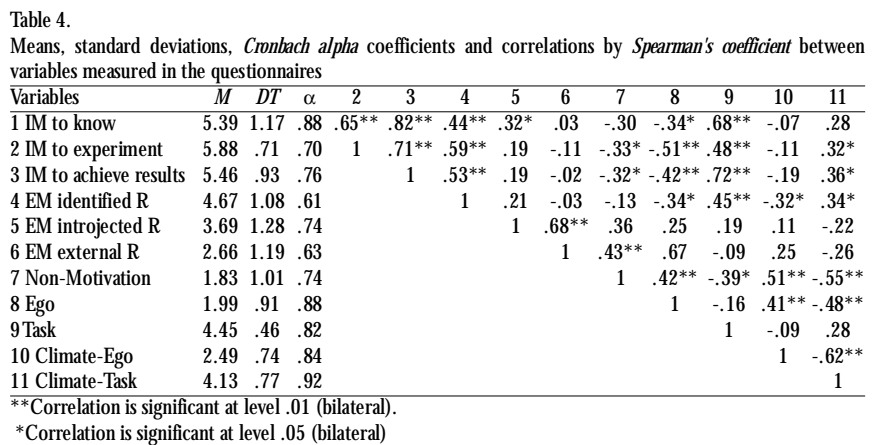

Means, standard deviations, Cronbach alpha coefficients and correlations by Spearman's coefficient between variables measured in the questionnaires

\begin{tabular}{lccccccccccccc}
\hline Variables & $M$ & DT & $\alpha$ & 2 & 3 & 4 & 5 & 6 & 7 & 8 & 9 & 10 & 11 \\
\hline 1 IM to know & 5.39 & 1.17 & 88 & $65^{* *}$ & $82^{* *}$ & $44^{* *}$ & $32^{*}$ & .03 & -30 & $-34^{*}$ & $68^{* *}$ & -.07 & 28
\end{tabular}

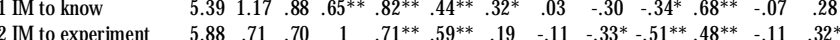

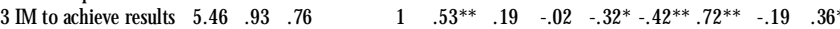

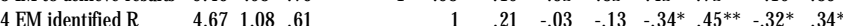

5 EM introjected

6 EM external $R \quad 2.661 .19 .63$

7 Non-M otivation $\quad 1.831 .01 .74$

$\begin{array}{lll}8 \text { Ego } & 1.99 .91 .88 \\ \text { 9Task } & 4.45 & .46 .82\end{array}$

$\begin{array}{lllll}9 \text { Task } & 4.45 & .46 & .82\end{array}$

\begin{tabular}{llll}
11 Climate-Task & 2.49 & .74 & .84 \\
\hline & 4.13 & .77 & .92
\end{tabular}

** Correlation is significant at level.01 (biatera

*Correlation is significant at level .05 (bilateral)

\section{Discussion}

The aim of this research was to study intrinsic and extrinsic motivation in three different female football teams, to analyse the evolution over the season of their goal orientations and their perceived motivational climate, as well as to find any possible difference between the competitive categories.

Beginning with the type of motivation, it was possible to verify through the Scale of Sporting M otivation that our players have an intrinsic motivation much higher than the extrinsic one, which means that they practise the sportjust for the pleasure and the satisfaction that it produces. These results are proved by other papers that show a higher intrinsic motivation both in female football (Granero, et al., 2015; Lizarazo, et al., 2018) and in male football (Bravo, et al., 2014; M oreno et al., 2007). Particularly, it has been proved that the intrinsic motivation to experiment is higher than the intrinsic motivation to achieve results, which means that our players practice their sport for the pleasure and satisfaction of perceiving different sensations from the usual ones, more than for the satisfaction experienced in correctly executing some exercise. The same results appear in Spanish football players of the $1^{\text {st }}$ Female Division (Granero et al., 2015) and in professional Colombian women footballers (Lizarazo et al., 2018), as in the study by Moreno et al. 2007) with female and male athletes of different sports. Among the extrinsic motivation, the motivation by regulation identified predominates, which representsthat our players, in some aspects practice their sport by external causes, although they have a greater autonomy and capacity to make decisions to get there, without the external cause to acquire some kind of reward. Granero et al. (2015) and Lizarazo et al. (2018) obtain the same results with their players, although with higher scores in all three variables.

Finally, the Amotivation is the variable with the lowest means, which is logical, given that our players al ways practice their sport under some motivation, as occurs in other studies (Bravo et al., 2015; Fernández et al., 2014; Lizarazo et al., 2018), as well as in other modalities (Moreno et al., 2007).

0 n the other hand, when comparing the results of this scale by categories, there are no differences found, showing a quite similar profile with a high intrinsic component. N either Sarmento et al. (2018), found differences in the self-determined motivation among the Portuguese male football categories, showing also a high intrinsic component.

Concerning goal orientations, we could see that throughout the season our players are clearly more taskoriented than ego-oriented, focusing their motivation on their level of performance, their ability to overcome and on their own dominance, and not on the comparison and competitiveness with the rest. The Portuguese footballers in the study by Sarmento et al. (2018) also showed a clear inclination to task without differences between the categories. These results are corroborated not only by other work of professional Spanish football players (Granero et al., 2015), but also in young male football players (Fernandez et al., 2014), and in professional female athletesin varioussports(FernandezRio et al. , 2017). M oreno et al. (2007) observed higher homework orientation scores for young female athletes than for boys in various sports. However, Lochbaum, Cetinkalp, Graham, W right \& Zazo (2016), in a quantitative review of goal orientations from 1989 to 2016 , conclude that there are no differences in goal orientations between genders or between categories of various sports.

When analysing the evolution of goal orientations throughout the season, we found that both ego and task 
orientation remain stable in the 1st Regional B Football 11 and 1st Regional Futsal categories, maintaining ahigh motivation for personal progress throughout the season, while a low motivation for competitiveness with teammates. N evertheless, in the category 2nd National football 11, the orientation to the task diminishes as it advances the season, which might be due to the slight fatigue both physical and psychological that can be accumulated in the course of the season, manifesting itself at the end of the same one. Fernández-Río et al. (2017) compared the goal orientation of female athletes before and after two different sports contexts, training and competition, showing no differences between the different situations in their goal orientation, but we have not found any work that analyses the evolution of goal orientation throughout the season, so that we could compare with our results.

In relation to the motivational climate perceived by our players we have observed that, throughout the season, there is a clear sense of involvement in the task, meaning that they perceive a climate focused on cooperative learning, recognition of improvements and efforts, and not a climate oriented towards competition, unequal treatment and rival ry between players. Iwasaki and Fry (2017) also find in teenage female football players, Ródenas (2019) in university football players and Fernández-Río et al. (2017), in female athletes of various sports, a climate clearly involved in the task. There are even studies that show that women have higher scores in the perception of the climate of involvement in the field of sports (M oreno et al., 2007; Chacón Cuberos et al., 2018).

$W$ hen comparing the perceived climates of the different categories a greater climate of involvement towards the competition is perceived in the 2nd $\mathrm{N}$ ational Football 11 category than in the rest of the categories, although it decreases as the season progresses. However, the climate of involvement in learning continues to predominate in the $\mathrm{N}$ ational category but is lower than in the rest of the categories at different times of the season. The opposite also occurs in the team of 1st Regional Futsal, which significantly decreases itsperception of the climate of involvement in the task at the end of the season, while the climate ego-involving increases. Seeing these results, we cannot reach clear conclusions about how the moment of the sports season affects the goal orientations and the perception of the climate; neither can we say that the differences between the teams are due to the different category they belong to, which may be due to their successes or failures in the competitions during the season or other variables, such as the influence that the coaches have when it comes to promoting a climate in the team (Álvarez et al., 2009). In this sense, Torregrosa et al. (2008) point out the relevance of the figure of the coach when it comes to developing a climate focused on effort and personal improvement, given the close relationship that exists between the climate involved in the task and sporting commitment, as has al so been demonstrated by various authors (Almagro et al., 2011; Álvarez, et al., 2009; Iwasaki \& Fry, 2016; Moreno et al., 2007; Torregrosa et al., 2008); being especially relevant in the youngest athletes where the coach is considered an important model to follow (Alesi, Gómez-López, Monteiro \& Granero, 2019). In addition, M onteiro et al. (2018), have shown in Portuguese football players that their autonomy is encouraged when the coach creates a motivational climate involved in thetask, wich can indirectly improve the results of the team. Furthermore, the perception of a climate involved in the task has been related to a greater acceptance of peers, and plenty more entretainment (Smith, et al., 2006), as well as a lower level of state anxiety (Castro-Sánchez, Zurita-O rtega, Chacón-Cuberos\& Lozano-Sánchez, 2019) and a greater conscious commitment to sport, specially, in the latter case, in women's football (Iwasaki \& Fry, 2016).

Concerning the possible relationships between the variables of the study, information from our players shows a positive relationship between self-determined motivation and task orientation and task climate. These same results can be found in several works with athletes (Granero et al., 2015; M onteiro et al. , 2014; Sarmento et al. , 2014), showing the adaptive role of having a high task orientation in promoting self-determination in sports (N toumanis, 2000) and the perception of a better motivational climate. A positive relationship has also been found between Amotivation and the orientation and climate of ego involvement, as well as negative relationships with orientation and task climate, as might be expected, given the meaning of Amotivation. However, we have not found the relationship between $M E$ and the orientation and climate towards the ego that appears in other works (Sarmento et al., 2014; Granero et al., 2015). Nevertheless, we have to emphasize the importance of the coach in promoting a self-determined motivation in his players, generating a climate oriented to the personal effort and the interest in the sport practice.

This research has enabled us to gain a better understanding of the women's football motivation, 
underlining the importance of generating effortinvolving climatesasa means of ensuring greater intrinsic motivation throughout the season. However, it has a number of limitations that should be highlighted: firstly, the sample is very small and compares categories of football and futsal, whose playing conditions are not exactly the same. It would also have been interesting to have information about the results of the games of each team in that season due to its possible influence on the motivational climate of the players. $0 \mathrm{n}$ the other hand, although the questionnaire EDM (SMS) has been used to measure self-determined motivation in multiple studies (f. e., Alesi et al, 2019; U rueña, Chinchilla \& Castillo, 2020), nevertheless does not measure extrinsic motivation by integrated regulation, as contemplated by Deci and Ryan's theory (1985), therefore leaving the measure incomplet.

It would be interesting in the future to continue studying motivation with larger samples that would allow for a greater generalisation of results, as well as to compare between men's and women's football, and to take into account other variables that may be influencing motivation during the season.

\section{References}

Alesi, M., Gómez-López, M., Borrego, C.C., Monteiro, D., \& Gallego-Granero, A. (2019). Effects of a motivational climate on psychological needs satisfaction, motivation and commitment in teen handball players. International Journal of Environmental Research and Public Heallth, 16, 2702; doi:10.3390/ ijerph16152702

Almagro, B. J., Sáenz-López, P., \& Moreno-Murcia, J. A. (2012) Perfilesmotivacionales de deportistasadolescentes españoles. Revista de Psicología del Deporte, 21(2), 223-231

Almagro, B.J., Sáenz, P., González-Cutre, D., \& M oreno, J.A. (2011). Clima motivacional percibido, necesidades psicológicas y motivación intrínseca como predictores del compromiso deportivo en adolescentes. Revista Internacional de Ciencias del Deporte, 7(25), 250-265. doi:10.5232/ ricyde2011.02501

Álvarez, M., Castillo, I., Duda, J.L., \& Balaguer, I. (2009). Clima motivacional, metas de logro y motivación autodeterminada en futbolistas cadetes. $R e$ vista de Psicología General y Aplicada, 62 (1-2), 35-44

Balaguer, I., Castillo, I., \& Tomás, I. (1996). Análisis de las propiedades psicométricas del Cuestionario de O rientación al Ego y a laTarea en el Deporte
(TEOSQ ) en su traducción al castellano. Psicología, (17), 71-81.

Balaguer, I., Castillo, I., \& Duda, J.L. (2003). ). Interrelaciones entre el clima motivacional y la cohesión en futbolistas cadetes. [Inter relations between motivational climate and cohesion in cadet footballers]. EduPsykhé:Revista de Psicología y Psicopedagogía, 2, 243-258.

Balaguer, I., Castillo, I., \& Duda, J.L. (2007). Propieda des psicométricas de la escala de motivación deportiva en deportistas españoles. Revista M exicana Psicología, 24(2), 197-207

Balaguer, I., Mayo, C., Atienza, F., \& Duda, J. L. (1997). Factorial validity of the Perceived Motivational Climate in Sport Questionnaire-2 in the case of Spanish elite female handball teams (abstract). Journal of Sport \& Exercise Psychology, 19, 27

Barroso, V., \& Amorim, V. (2007). Verificação do clima motivacional em atletas femeninas do futsal: un estudo com o questionário de orientação para tarefa ou ego (TEO SQ ). Revista Mackenzie de Educação Física eEsporte, 6(3), 207-2013

Barroso, V., Lopes, C.E., \& De Marco, A. (2017). TEOSQ factorial exploration of youth Brazilian soccer players. Journal of Physical Education and Sport, 17(1), 355-360

Bravo, A. G., Tirira, B., Ponce, P. M., \& Arla, M. (2015). Análisis de la escala de motivación deportiva en la categoría sub16 de la escuela de fútbol 'El Nacional'. Lecturas: Educación Física y Deportes, 211. Recuperado dehttp:/ / www. efdeportes.com/ efd211/ escala-demotivacion-deportiva-en-futbol. htm

Castillo, I., Balaguer, I., \& Duda, J.L. (2000). Las orientaciones de meta y los motivos de práctica deportiva en los jóvenes deportistas valencianos escolarizados. Revista de Psicología del Deporte, 9(1-2), 37-50

Castro-Sánchez, M., Zurita-O rtega, F., Chacón-Cuberos, R., \& Lozano-Sánchez, A.M. (2018). Clima motivacional y niveles de ansiedad en futbolistas de categorías inferiores. Retos, 35, 164-169

Cecchini, J. A.; González, C.; López-Prado, J. , \& Brustad, R. J. (2005). Relación del clima motivacional percibido con la orientación de meta, la motivación intrínseca y las opiniones y conductas de fair play. Revista M exicana de Psicología, 22, 469-479.

Chacón-Cuberos, R., Zurita-O rtega, F., ChacónZagalaz, J., Espejo-Garcés, T., Castro-Sánchez, M., \& Pérez-Cortés, A.J. (2018). Clima motivacional percibido hacia el deporte en estudiantes universi- 
tarios de educación física. Apunts. Educación Física y Deportes. 131, 49-59. decihttp:/ / dx. doi.org/ 10.5672/ apunts.2014-0983.es. (2018/1).131.04

Deci, E.L., \& Ryan, R.M. (1985). The general causality orientations scale: Selfdetermination in personality. Journal of Research in Personality, 19, 109-134. https:/ / doi.org/ 10.1016/ 0092-6566(85)90023-6

Deci, E. L. \& Ryan, R.M. (2000).The «what» and «why» of goal pursuits: human needs and the selfdetermination of behavior. Psychological Inquiry, 11(4), 227-268.

Dosil, J. (2004). Psicología de la Actividad física y del Deporte. Madrid: M cGraw Hill

Duda, J.L., \& Nicholls, J.G. (1989). Relationship between task and ego orientation and the perceived purpose of sport among high school athletes. Journal of Sport \& Exercise Psychology, 11, 318-335

Fernández, R.C., Yagüe, J.M., M olinero, O., Márquez, S., \& Sal guero, A. (2014). A nál isis de las diferencias motivacionales entre el fútbol 7 y el fútbol 11. Cuadernos de Psicología del Deporte, 14(2), 47-58

Fernández-Ríos, J., Cecchini, J. A., \& M éndez-J iménez, A. (2017). Does Context, Practice or Competition Affect Female Athletes' Achievement Goal Dominance, Goal Pursuit, Burnout and M otivation? Journal of human kinetics, 59(1), 91-105. https:/ / doi.org/ 10.1515/ hukin-2017-0150

Galván, J.F., López, J.M., Pérez, J.A., Tristán, J.L., \& Medina, R.E. (2013). Clima motivacional en deportesindividualesy de conjunto en atletasjóvenesmexicanos. Revista Iberoamericana de Psicología del Ejercicio y el Deporte, 8(2), 393-410

García Navieira, A., \& Remor, E. (2011). Motivación delogro, indicadores de competitividad y rendimiento en un equipo de jugadores de fútbol de competición varones entre 14 y 24 años. Universitas Psychologica, 10(2), 477- 487

González, C., Cecchini, J.A., Llavona, A., \& Vázquez, A. (2010). Influencia del entorno social y el clima motivacional en el autoconcepto de las futbolistas asturianas. Aula Abierta, 38(1), 25-36

Granero, A., Gómez, M., Abraldes, J.A., \& Bæena, A. (2015). Predicción de las orientaciones de meta en el fútbol femenino. Journal of Sport and $H$ ealth Research, 7(1), 31-42

Iso-Ahola, S. \& St.Clair, B. (2000). Toward aTheory of Exercise M otivation. Quest, 52 (2), 131-147. https:/ / doi.org/ 10.1080/ 00336297.2000.10491706

Iwasaki, S., \& Fry, M. D. (2016). Female adolescent soccer players' perceived motivational climate, goal orientations, and mindful engagement. Psychology of Sport and Exercise, 27, 222-231. https:/ / doi.org/ 10.1016/ j.psychsport.2016.09.002

Lizarazo, N.L., O rtiz, K.D., \& Acuña, L.C. (2018). Factores motivacionales para la práctica de fútbol profesional femenino en tres (3) clubes de Santander (TFG). U niversidad Santo Tomás, Bucaramanga, Colombia

Lochbaum, M., Cetinkalp, Z.K., Graham, K.A., W right, T. , \& Zazo, R. (2016). Task and ego goal orientations in competitive sport: a quantitative review of the literature from 1989 to 2016. Kinesiology 48(1), 3-29 Martín, G. (2003). La mujer futbolista desde la perspectivapsicológica. Cuadernos de Psicología del Deporte, 3(2), 7-15

Monteiro, D., M outão, J., Baptista, P., \& Cid, L. (2014). Clima motivacional, regulação da moyivação e perceção de esforço dosatletasno futebol. Motricidade, 10(4), 94-104. http:/ / dx. doi.org/ 10.6063/ motricidade. 10(4). 3453

Monteiro, D., Teixeira, D.S., Travassos, B., DuarteMendes, P., M outão, J., M achado, S. \& Cid, L. (2018). Perceived Effort in Football Athletes: The Role of Achievement Goal Theory and Self-Determination Theory. Frontiers in Psychollogy, 9, 1575. https:/ / doi.org/ 10.3389/ fpsyg. 2018.01575

Moreno, J. A., \& Martínez, A. (2006). Importancia de laTeoría de laAutodeterminación en la práctica físico-deportiva: Fundamentos e implicaciones prácticas. Cuadernos de Psicología del Deporte, 6(2), 39-54

Moreno, J.A., Cervelló, E., \& Gonzalez-Cutre, D. (2007). Analizando la motivación en el deporte: un estudio a través de la teoría de la autodetermina ción. Apuntes de Psicología, 25(1), 35-51

Navarrón, E., Asenjo, R., \& Rodríguez, A. (2012). La preparación psicológica en un equipo de fútbol sala femenino. C.D. Universidad de Granada

Newton, M., Duda, J. L., \&Yin, Z. (2000). Examination of the Psychometric Properties of the Perceived Motivational Climate in Sport Q uestionnaire-2 in a Sample of Female Athletes, Jourmal of Sport Sciences, 18, 275-290. https:// doi.org/ 10.1080/ 026404100365018

Nicholls, J. G. (1984). Achievement motivation: Conceptions of ability, subjective experience, task choice, and performance. Psychological Review, 91(3), 328-346. https:// doi.org/ 10.1037/ 0033295X.91.3.328

$N$ toumanis, N. (2001). Empirical links between achievement goal theory and self-determination theory in sport. Journal of Sports Sciences, 19(6), 397- 
409.https:/ / doi.org/ 10.1080/ 026404101300149357

Núñez-Alonso, J.L., Martín-Albo, J., \& Navarro, J.G. (2007). Psychometric properties of the Spanish ver sion of the sport motivation scale. Revista de Psicología del D eporte, 16(2), 211-223.

Pelletier, L.G., Fortier, M.S., Vallerand, R.J., Tuson, K.M., Briere, N.M., \& Blais, M.R. (1995). Toward a new measure of intrinsic motivation, extrinsic motivation, and amotivation in sports: The sport motivation scale (SMS). Journal of Sport and Exercise Psychology, 17, 35-53. https:/ / doi.org/ 10.1123/ jsep.17.1.35

Pérez-M uñoz, S. , Sánchez, J., \& U rchaga, J. D. (2015). Los motivos para la participación en fútbol: Estudio por categorías y nivel de competición de los jugadores. Cultura, Ciencia y D eporte, 10(30), 187-198. http:/ / dx. doi.org/ 10.12800/ ccd.v10i30.588

Pérez-M uñoz, S., Castaño, R., Sánchez, A., Rodríguez, A., De Mena, J.M., Fuentes, J.M., \& Castaño, C. (2018). ¿Por qué juego al fútbol si soy una mujer?: M otivaciones parajugar al fútbol. Retos, 34, 183-188

Reyes, M. (2009). Clima motivacional y orientación de meta en futbolistas peruanos de primera división. Cuadernos de Psicología del D eporte, 9(1), 5-20

Ródenas, L.Y. (2019). Análisis de la relación entre cohesión y clima motivacional en el fútbol femenino mexicano. Revista Iberoamericana de Psicología del Ejercicio y del Deporte, 14(2), 97-101

Ruiz-J uan, F., Pieron, M., \& Zamarripa, J. (2014).Versión española del «Task and Ego 0 rientation in Sport Q uestionnaire (TEOSQ )» adaptado a Educación Física. Estudios de Psicología, 32(2), 179-193

Ryan, R. M., \& Deci, E. L. (2020). Intrinsic and extrinsic motivation from a self-determination theory perspective: Definitions, theory, practices, and future directions. Contemporary Educational Psychology, 61, 1- 11.https://doi.org/10.1016/ j.cedpsych. 2020.101860

Sáenz-López P., Jiménez Sánchez, A.C., Giménez, F.J., Ibáñez, S.J. (2007). La autopercepción de las jugadoras de baloncesto expertas respecto a sus procesos de formación. Cultura, Ciencia y D eporte, 3(7), 35-41.

Sarmento, H., M arcelino, R. , Anguera, M., Campaniço, J., Matos, N., \& Leitão, J. (2014). Match analysis in football: Asystematicreview. Journal of Sports Sciences, 32(20), 1831-1843. https:/ / doi.org/ 10.1080/ 02640414.2014 .898852

Sarmento, H., Peralta, M., Harper, L., Vaz, V., \& Marques, A. (2018). A chievement goals and selfdetermination in adult football players - a cluster analysis. Kinesiology, 50, 43-51. https:/ / doi.org/ $10.26582 /$ k.50.1.1

Torregrosa, M., Sousa, C., Viladrich, C., Villamarín, F., $\&$ Cruz, J. (2008). El clima motivacional y el estilo de comunicación del entrenador como predictores del compromiso en futbolistas jóvenes. Psicothema, 20(2), 2008, 254-259

U reña, Ch., Chinchilla-Minguet, J.L., \& CastilloRodríguez, A. (2020). Relación de la motivación y el flow situacional en futbolistassub16 en estado basal yprecompetitivo. Retos, 37, 480-485

Vallerand, R. J., Blais, M. R., Brière, N. M., \& Pelletier, L. G. (1989). Construction et validation de l'échelle demotivation en éducation (EME) [Construction and validation of the M otivation toward Education Scale]. Canadian Journal of Behavioural Science / Revue canadienne dessciencesdu comportement, 21(3), 323- 349. https:/ / doi.org/ 10.1037/ h0079855

Walling, M.D., Duda, J.L., \& Chi, L. (1993). The Perceived Motivational Climate in Sport Questionnaire: Construct and Predictive Validity. Journal of Sport and Exercise Psychology, 15(2), 172-183. https:/ / doi.org/ 10.1123/ jsep.15.2.172

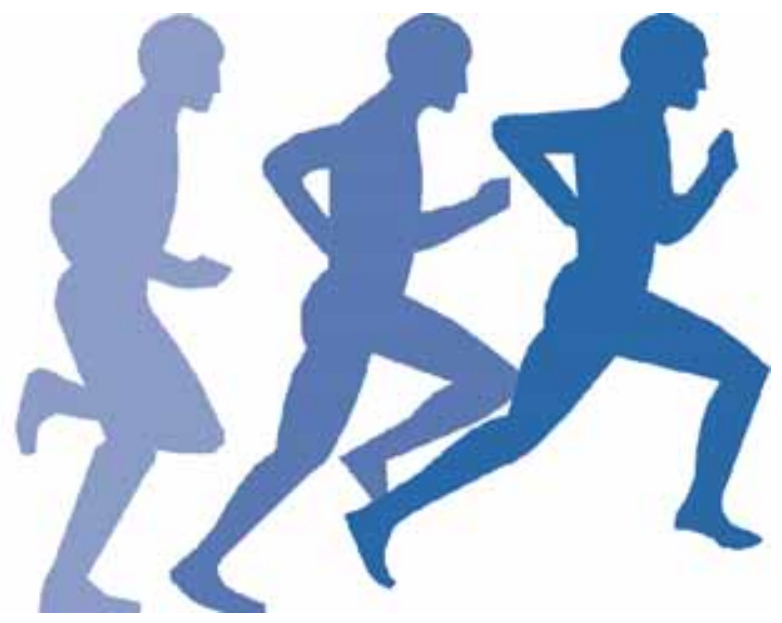

